This item was submitted to Loughborough's Research Repository by the author.

Items in Figshare are protected by copyright, with all rights reserved, unless otherwise indicated.

\title{
Experimental and analytical analysis of polarization and water transport behaviors of hydrogen alkaline membrane fuel cell
}

PLEASE CITE THE PUBLISHED VERSION

https://doi.org/10.1016/j.jpowsour.2018.02.020

PUBLISHER

(C) Elsevier

VERSION

AM (Accepted Manuscript)

\section{PUBLISHER STATEMENT}

This work is made available according to the conditions of the Creative Commons Attribution-NonCommercialNoDerivatives 4.0 International (CC BY-NC-ND 4.0) licence. Full details of this licence are available at: https://creativecommons.org/licenses/by-nc-nd/4.0/

\section{LICENCE}

CC BY-NC-ND 4.0

\section{REPOSITORY RECORD}

Huo, Sen, Jiaxun Zhou, Tianyou Wang, Rui Chen, and Kui Jiao. 2018. "Experimental and Analytical Analysis of Polarization and Water Transport Behaviors of Hydrogen Alkaline Membrane Fuel Cell”. figshare. https://hdl.handle.net/2134/28460. 


\title{
Experimental and analytical analysis of polarization and water transport behaviors of hydrogen alkaline membrane fuel cell
}

\author{
Sen $\mathrm{Huo}^{\# 1}$, Jiaxun Zhou ${ }^{\# 1}$, Tianyou Wang ${ }^{1}$, Rui Chen $^{1,2}$, Kui Jiao ${ }^{* 1}$ \\ ${ }^{1}$ State Key Laboratory of Engines, Tianjin University, 135 Yaguan Rd, Tianjin, China, 300350 \\ ${ }^{2}$ Department of Aeronautical and Automotive Engineering, Loughborough University, \\ Leicestershire LE11 3TU, UK \\ *Corresponding author email: kjiao@tju.edu.cn (K. Jiao) ; \#. equal contribution
}

Accepted for publication by Journal of Power Sources (February 2018)

\begin{abstract}
Experimental test and analytical modeling are conducted to investigate the operating behavior of an alkaline electrolyte membrane (AEM) fuel cell fed by $\mathrm{H}_{2} /$ air $\left(\right.$ or $\mathrm{O}_{2}$ ) and explore the effect of various operating pressures on the water transfer mechanism. According to the experimental test, the cell performance is greatly improved through increasing the operating pressure gradient from anode to cathode which leads to significant liquid water permeation through the membrane. The high frequency resistance of the A901 alkaline membrane is observed to be relatively stable as the operating pressure varies based on the electrochemical impedance spectroscopy (EIS) method. Correspondingly, based on the modeling prediction, the averaged water content in the membrane electrode assembly (MEA) does not change too much which leads to the weak variation of membrane ohmic resistance. This reveals that the performance enhancement should give the credit to better electro-chemical reaction kinetics for both the anode and cathode, also prone by the EIS results. The reversion of water back diffusion direction across the membrane is also observed through analytical solution.
\end{abstract}

Keywords: alkaline electrolyte membrane fuel cell; experimental test; analytical model; water transport. 


\section{Introduction}

Fuel cells have been touted as a popular alternative clean energy conversion device due to its high power density, low emission, fast startup and high thermal efficiency, acquiring increased interests from commercial, governmental, military and academic organizations [1-4]. Alkaline electrolyte membrane $(A E M)$ fuel cell offers potential superiority over the conventional proton exchange membrane (PEM) fuel cell, most dramatically to surmount the precious catalyst dependence which greatly encumbers the commercial implementation. AEM fuel cell is considered to generate from alkaline fuel cell (AFC) which seriously suffers from the carbon dioxide $\left(\mathrm{CO}_{2}\right)$ poisoning problem. The fast commercialization of AEM makes it possible for the AFC to overcome to the poisoning problem $[5,6]$.

Recently, many experimental studies on the AEM fuel cell have been carried out to investigate the operating behavior with various cell designs and different operational conditions [7-19]. Compared to the well-developed PEM fuel cell, the researches on AEM fuel cell are still at early stage. A novel membrane electrode assembly (MEA) based on the porous silver electrode has been designed by Kucernak et al. [7] and an enhanced performance of $60 \mathrm{~mW} \mathrm{~cm}^{-2}$ at $0.6 \mathrm{~V}$ has been obtained. The effect of the electrode design parameters, including the ionomer content, thickness of catalyst layer $(\mathrm{CL})$ and membrane and aminating agent of the membrane, on the performance of AEM fuel cell has been investigated by Mamlouk et al. [8]. The experimental tests were also carried out by Yang et al. [9] to optimize the design parameters of the gas diffusion layer (GDL), PTFE content and catalyst loading, and a peak power density of $213 \mathrm{~mW} \mathrm{~cm}^{-2}$ was achieved at $50{ }^{\circ} \mathrm{C}$. In addition, high performance AEMs and non-precious catalysts have been prepared to enhance the MEA performance $[5,6,10-14]$. With the design of AEM fuel cell getting improved, a series of experimental researches on the performance test, control strategy and water management are emerging in the literature. The importance of dynamic water balance between membrane and electrode water uptake was demonstrated by Omasta et al. for the performance enhancement [15]. Anode flooding issue has been also declared by Oshiba et al. [16] and efficient water management strategies by changing the membrane thickness and anode flow rate has been proposed. The critical relation 
between the electrochemical stability and water content inside the electrode was addressed based on the experimental work and molecular dynamics modeling [17]. The overall cell performance under various operating conditions has been tested using an AEM fuel cell containing A201 alkaline membrane as the solid electrolyte [18]. Early researches on the fuel cell design and operating performance has deeply facilitated the development of AEM fuel cell technology. However, the experimental investigation on the hydrogen AEM fuel cell is still scarce and immature, and the operating characteristics, especially the water transport behavior and management strategy still need to be further explored [19].

Water balance should be recognized as a critically pivotal issue for AEM fuel cell with increasing rigor. Several water transport approaches should be addressed inside the cell, covering the water back diffusion, electro-osmotic drag effect and liquid permeation though the alkaline membrane. Considering the complexity and difficulty of the visualization research on fuel cell, modeling study is viewed to be a more effective and low-cost approach to gain a deep insight into the water transport in the porous electrodes and alkaline membrane. Modeling study has been proposed and demonstrated by Raya et al. [20] and the coupling of the membrane conductivity with the water absorption and temperature has been emphasized. Dekel et al. [21] presented a new model for hydrogen AEM fuel cell and the critical dependence of cell performance on the cathode hydration was stated. Sommer et al. [22] also developed a transient model for AEM fuel cell to predict the cell response with respect to the physical properties and operation/design parameters. A series of multi-dimensional multiphase modeling work has been conducted for hydrogen AEM fuel cell in the last several years [23-29], pointing out the importance of water management in AEM fuel cell. However, in these early modeling studies on AEM fuel cell, the water transport mechanism is still not impeccable and needs to be further developed. One important issue is that the models for AEM fuel cell need to be validated more comprehensively to reveal the transport mechanism precisely.

In this present work, experimental and modeling work is conducted to further explore the operating behavior of AEM fuel cell, as well as the water transport inside the electrode. The polarization losses are obtained using in-situ electrochemical impedance spectroscopy (EIS) method. An 
analytical model is also developed to simulate the transport characteristics inside the cell based on the experimental data and promotes understanding of the operating behavior under different operating conditions. It should be noted that the liquid permeation through the membrane is also taken into consideration which was often neglected in previous studies and its significant influence on the cell performance and mass transport is also discussed. The detailed experimental setup and analytical modeling formulation is introduced in the second and third sections, respectively. The experimental and analytical results are presented in the fourth section, followed by the conclusion in the last section.

\section{Experiment}

\subsection{Experimental Setup and Procedures}

The schematic of experimental setup is shown in Figure 1, composed of the testing AEM fuel cell, fuel cell test station, environment chamber, electrochemical station and data processing system. The fuel cell test station is used for controlling and monitoring the operating parameters for the fuel cell tests, such as the humidification condition, stoichiometry ratio, flow rate, operational current or voltage, feed gases species and back pressures. The deionized water is utilized for humidifying the feed gases based on bubbling humidification. The environment chamber is applied for heating up (or cooling down) and maintaining the fuel cell and operating environment at a specific operating temperature. The in-situ polarization losses, as well as the high frequency impedance of the testing fuel cell can be captured and estimated via the EIS method utilizing the electrochemical station. The equivalent circuit for the EIS data is also presented in Figure 1. The measurement of back pressure is implemented at both anode and cathode outlets. Meanwhile, the data are constantly collected by the data processing system during the fuel cell tests. 


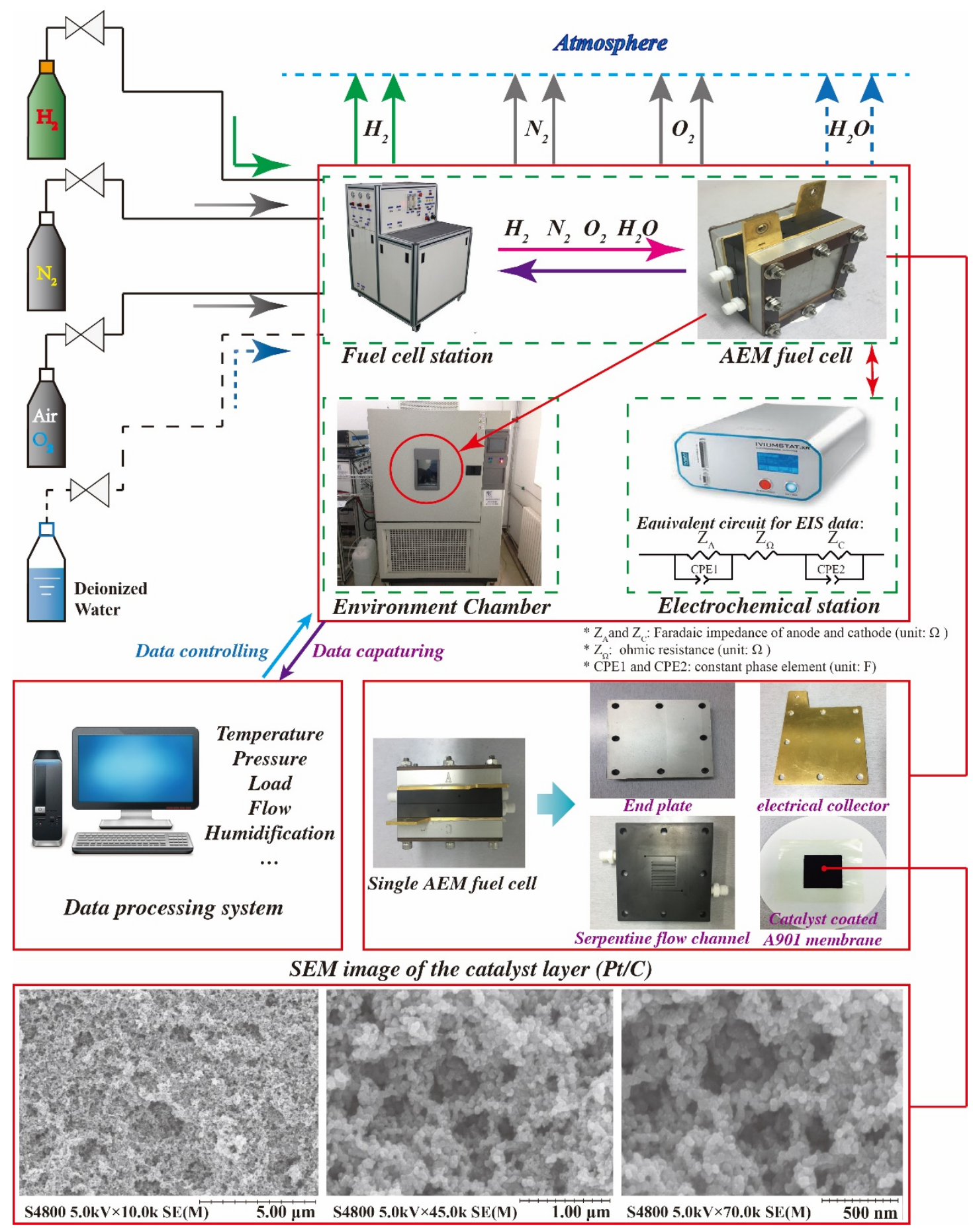

Figure 1. Schematic of the experimental setup.

\subsection{Fuel Cell Design and MEA Fabrication}

The testing AEM fuel cell consists of end plates (aluminum alloy), electrical collectors (gold coated aluminum alloy), graphite flow fields with flow channel and catalyst coated membrane (CCM). The testing AEM fuel cell has a serpentine flow channel with a cross section area of $0.8 \mathrm{~mm}$ by $1.0 \mathrm{~mm}$ and active area of $2.5 \mathrm{~cm}$ by $2.5 \mathrm{~cm}$. A commercial A901 alkaline membrane from Tokuyama 
Corporation is selected as the solid alkaline electrolyte. The catalyst loading of Pt is set as $0.5 \mathrm{mg}$ $\mathrm{cm}^{-2}$ for both electrodes. The MEA is prepared by sandwiching the GDLs with micro-porous, carbon-based layer (MPL) and the CCM. The GDL used in the test is $\mathrm{H} 23 \mathrm{C} 6$ from Freudenberg Group which contains a macro-porous superstructure (carbon fiber paper) and MPL. The thickness of GDL is around $250 \mu \mathrm{m}$ with consideration of the MPL. The weight ratio between Pt/C and ionomer in the $C L$ is set as 3:1 to maintain effective electrochemical kinetics and ionic conductivity inside CL. The scanning electron microscope (SEM) images of the CL surface are also given in Figure 1. The basic information and physical properties of AEM fuel cell are listed in Table 1.

Table 1. Basic information and physical properties of the testing AEM fuel cell.

\begin{tabular}{ll}
\hline Parameters & Value \\
\hline Flow channel & Serpentine \\
Length; width; height of flow channel & $1 \mathrm{~mm} ; 1 \mathrm{~mm} ; 1 \mathrm{~mm}$ \\
Width of the rib on the flow channel & $1 \mathrm{~mm}$ \\
Thickness of alkaline anion exchange & $10 \mu \mathrm{m}$ \\
membrane & \\
Thickness of gas diffusion layer (GDL) & $250 \mu \mathrm{m}$ \\
Thickness of catalyst layer (CL) & $10 \mu \mathrm{m}$ \\
Porosity of GDL;MPL;CL & $0.6 ; 0.3 ; 0.15$ \\
Contact angles of GDL; MPL; CL & $110^{\circ} ; 120^{\circ} ; 95^{\circ}$ \\
Catalyst loading of Pt in CL & $0.5 \mathrm{mg} \mathrm{cm}$ for both anode and cathode \\
weight ratio between Pt/C and ionomer in CL & $3: 1$ \\
Active area & $6.25^{\star} 10^{-4} \mathrm{~m}^{2}$ \\
\hline
\end{tabular}

As for the preparation of the $\mathrm{CCM}$, the $\mathrm{Pt} / \mathrm{C}$ (Pt $56.6 \%$ wt.) is calculated as $5.52 \mathrm{mg}$ in terms of the Pt loading of $0.5 \mathrm{mg} \mathrm{cm}^{-2}$ and the active area of $6.25 \mathrm{~cm}^{2}$. Pt/C should be firstly infiltrated by the deionized water of $50 \mathrm{mg}$ and then mixed with the normal propyl alcohol solution $(1 \mathrm{~mL})$ due to the fact that the direct contact between dry Pt/C and normal propyl alcohol solution possibly leads to fire risk. According to the weight ratio between $\mathrm{Pt} / \mathrm{C}$ and ionomer in the $\mathrm{CL}(3: 1)$, the required amount of the ionomer solution (alkaline electrolyte $5 \% \mathrm{wt}$.) is $36.81 \mathrm{mg}$. The catalyst-ionomer ink is prepared by mixing the ready-made catalyst ink with the ionomer solution. Sonication is implemented on the catalyst-ionomer ink for $90 \mathrm{~min}$ for better mixture. At last, the CCM is fabricated via spraying the catalyst-ionomer ink onto the A901 alkaline membrane under infrared spotlight. In order to facilitate 
the solidification of $\mathrm{Pt} / \mathrm{C}$ and the volatilization of normal propyl alcohol, vacuum heating is employed and the heating temperature is set as $50^{\circ} \mathrm{C}$.

\subsection{Experimental test}

The polarization test is conducted in constant-voltage mode, which is separated into two cases by feeding $\mathrm{H}_{2} /$ air and $\mathrm{H}_{2} / \mathrm{O}_{2}$ for the testing AEM fuel cell. The flow rates at anode and cathode inlets are 0.5 and $1.0 \mathrm{slpm}$, respectively. Since the gas supply is conducted based on the inlet flow rate via the fuel cell test station, the actual stoichiometry ratio varies with the operating current density. The normal operating temperature of AEM fuel cell is set at around $50{ }^{\circ} \mathrm{C}$ which is slightly lower than the conventional PEM fuel cell in order to achieve both the effective membrane performance and operational durability. Through setting the dew point temperature at $50^{\circ} \mathrm{C}$, fully humidified hydrogen and air or $\mathrm{O}_{2}$ are supplied.

\section{Model}

\subsection{Physical problem}

In order to comprehensively understand and quantify the cell performance and mass transport mechanism inside the AEM fuel cell, modeling work should be carefully formulated. It is known that water is generated in anode and consumed in cathode of an AEM fuel cell which may generally result in the water concentration gradient from anode to cathode, further leading to water back diffusion through the alkaline membrane. The water molecular may be also combined with the hydroxyl ion $\left(\mathrm{OH}^{-}\right)$in the cathode $\mathrm{CL}$ and attracted by the positive charges in the anode to migrate towards anode, generally known as electro-osmotic drag effect. Liquid water permeation should be also accounted as another critical water transport phenomenon through the membrane due to the intrinsic permeable property of the polymer membrane, which is rarely considered in the previous modeling studies on AEM fuel cell and should be equally stressed. Since liquid water permeation is caused by the liquid pressure difference between the anode and cathode and its influence can be significantly amplified by different operating pressures. A single AEM fuel cell with a single straight flow channel is considered as the computational domain. The modeling work comprehensively identifies the electrochemical reactions and multiphase flow throughout the electrodes in which the 
liquid water saturation jump at the interface is also performed using liquid pressure continuity method. The modeling parameters follow rigidly the physical properties given by Table 1, as well as the base operating condition.

\subsection{Assumptions}

(1) The gas flow considered in this model follows the ideal gas law.

(2) The flow is in laminar state due to the small Reynolds number of the flow.

(3) Steady-state and isothermal conditions are assumed.

(4) The amount of liquid water is fixed to be zero in the flow channel which means it will be immediately removed from the flow field mainly because of the fast flow rate in the flow channel (anode: $0.5 \mathrm{slpm}$, cathode: $1.0 \mathrm{slpm}$ ) and small size of the computational domain being implemented in this study.

(5) Owing to the fully humidified gases considered in the experimental test and modeling work, the water generated in the anode $\mathrm{CL}$ is in liquid phase at $50^{\circ} \mathrm{C}$.

(6) The A901 alkaline membrane is considered to be impermeable to the gas phase.

\subsection{Formulation}

\subsubsection{Cell output}

The reversible voltage $\left(V_{0}, V\right)$ of the electrochemical reaction is determined by the Nernst Equation [22]:

$V_{\text {nernst }}=1.229+0.846 \times 10^{-3}\left(T-T_{\text {ref }}\right)+\frac{R T}{2 F}\left(\ln \left(p_{\mathrm{H}_{2}}\right)+\frac{1}{2} \ln \left(p_{\mathrm{O}_{2}}\right)\right)$

where $T$ and $T_{r e f}(298 \mathrm{~K})$ denotes the operating temperature and reference operating temperature of the AEM fuel cell. $R$ refers to the universal gas constant $\left(8.314 \mathrm{~J} \mathrm{~mol}^{-1} \mathrm{~K}^{-1}\right) . F$ stands for the Faraday's constant $\left(96487 \mathrm{C} \mathrm{mol}^{-1}\right) . \quad p_{\mathrm{H}_{2}}$ and $p_{\mathrm{O}_{2}}$ represent the partial pressures for $\mathrm{H}_{2}$ and $\mathrm{O}_{2}$.

The ohmic overpotential is composed of the ohmic voltage losses in the fuel cell components, involving the bipolar flow fields $\left(\eta_{\mathrm{ohm}-\mathrm{P}}, V\right)$, porous electrodes $\left(\eta_{\mathrm{ohm}-\mathrm{por}}, V\right)$ and alkaline membrane 
$\left(\eta_{\text {ohm-m }}, V\right)$, which can be calculated as follows:

$\eta_{\text {ohmic }}=\eta_{\text {ohm-P }}+\eta_{\text {ohm-por }}+\eta_{\text {ohm-m }}$

It should be noted that the ohmic overpotential in the bipolar plates $\left(\eta_{\mathrm{ohm}-\mathrm{P}}, V\right)$ is caused by the electron transport, which should be determined according to the electrical conductivity of electron. The same is true with the porous GDL. As for the CL, the electrical conductivity is constituted by the electron transfer in the carbon backing support and $\mathrm{OH}^{-}$transfer in the alkaline electrolyte. Therefore, partial thickness of $\mathrm{CL}$ needs to be considered in calculations of the electrical conductivity and ionic conductivity, depending upon the reaction site in CL. In the modeling work, half thickness of $\mathrm{CL}$ is used for the resistances of electron and $\mathrm{OH}^{-}$by assuming the electrochemical reaction taking place in the middle site of $\mathrm{CL}$. The effective ionic conductivity, $\sigma_{\mathrm{m}}^{\text {eff }}\left(\mathrm{S} \mathrm{m}^{-1}\right)$, and electrical conductivity, $\sigma_{\mathrm{s}}^{\text {eff }}\left(\mathrm{S} \mathrm{m}^{-1}\right)$, inside $\mathrm{CL}$ are solved by the Bruggeman's correlation [30]:

$$
\begin{aligned}
& \sigma_{\mathrm{m}}^{\mathrm{eff}}=\sigma_{\mathrm{m}} \cdot \omega^{1.5} \\
& \sigma_{\mathrm{s}}^{\mathrm{eff}}=\sigma_{\mathrm{s}} \cdot(1-\varepsilon-\omega)^{1.5}
\end{aligned}
$$

in which $\sigma_{\mathrm{m}}$ and $\sigma_{\mathrm{s}}$ represent the intrinsic ionic and electrical conductivity inside $\mathrm{CL}$, respectively. $\omega$ and $\varepsilon$ denote the volume fraction of ionomer and porosity in the $\mathrm{CL}$, respectively. The Butler-Volmer Equation relates the reaction rate $\left(J_{i}, \mathrm{~A} \mathrm{~m}^{-3}\right)$ to the activation overpotential $\left(\eta_{\mathrm{act}}, V\right)$ and mathematically outlines the influences of the operating temperature and reactant concentration on the cell performance:

$$
J_{i}=J_{\text {ref }}\left(\frac{C_{i}}{C_{i, \text { ref }}}\right)^{r_{i}}\left[\exp \left(\frac{\alpha n F}{R T} \eta_{\text {act }}\right)-\exp \left(-\frac{\alpha n F}{R T} \eta_{\text {act }}\right)\right]
$$

In the modeling work, the effect of liquid occupation on the electrochemical reaction is accounted. Therefore, the Butler-Volmer Equation can be corrected by the liquid water amount in the CL and transformed into the expression as below:

$$
J_{i}=\left(1-s_{\mathrm{lq}}\right) J_{\text {ref }}\left(\frac{C_{i}}{C_{i, \text { ref }}}\right)^{r_{i}}\left[\exp \left(\frac{\alpha n F}{R T} \eta_{\text {act }}\right)-\exp \left(-\frac{\alpha n F}{R T} \eta_{\text {act }}\right)\right]
$$

in which $J_{\text {ref }}\left(\mathrm{A} \mathrm{m}^{-3}\right)$ is the reference exchange current density of the reaction. $s_{\mathrm{lq}}$ represents the 
liquid water volume fraction on the reaction site. $C_{i}$ and $C_{i, \text { ref }}\left(\mathrm{mol} \mathrm{m}^{-3}\right)$ are the local molar concentration and reference molar concentration of reactant species $i$ (anode: $\mathrm{H}_{2}$, cathode: $\mathrm{O}_{2}$ and $\mathrm{H}_{2} \mathrm{O}$ ) on the reaction site. $r_{i}$ means the order of the reaction which equals to 1 in this study.

Through mathematical derivation, the activation overpotential for anode and cathode semi-reaction ( $\eta_{\text {act }}^{\text {anode }}$ and $\eta_{\text {act }}^{\text {cathode }}, V$ ) can be analytically solved by:

$$
\begin{gathered}
\eta_{\text {act }}^{\text {anode }}=\frac{R T}{\alpha n F} \cosh ^{-1}\left[\frac{I^{2}}{4 \sigma_{\mathrm{m}}^{\text {eff } 2}\left(\frac{\sigma_{\mathrm{m}}^{\text {eff }}+\sigma_{\mathrm{s}}^{\text {eff }}}{\sigma_{\mathrm{m}}^{\text {eff }} \sigma_{\mathrm{s}}^{\text {eff }}}\right)\left(\frac{R T}{\alpha n F}\right)\left(1-s_{\mathrm{lq}}\right) J_{\text {ref }}^{\text {anode }}\left(\frac{C_{\mathrm{H}_{2}}}{C_{\mathrm{H}_{2}, \text { ref }}}\right)}+1\right] \\
\eta_{\text {act }}^{\text {cathode }}=\frac{R T}{\alpha n F} \cosh ^{-1}\left[\frac{I^{2}}{4 \sigma_{\mathrm{m}}^{\text {eff } 2}\left(\frac{\sigma_{\mathrm{m}}^{\text {eff }}+\sigma_{\mathrm{s}}^{\text {eff }}}{\sigma_{\mathrm{m}}^{\text {eff }} \sigma_{\mathrm{s}}^{\text {eff }}}\right)\left(\frac{R T}{\alpha n F}\right)\left(1-\mathrm{s}_{\mathrm{lq}}\right) J_{\text {ref }}^{\text {cathode }}\left(\frac{C_{\mathrm{O}_{2}}}{C_{\mathrm{O}_{2}, \text { ref }}}\right)\left(\frac{C_{\mathrm{H}_{2} \mathrm{O}}}{C_{\mathrm{H}_{2} \mathrm{O}, \text { ref }}}\right)}+1\right]
\end{gathered}
$$

The detailed derivation has been elaborated upon in our previous study $[23,24]$ which is not presented in this work. I $\left(\mathrm{A} \mathrm{m}^{-2}\right)$ is the operating current density.

By coupling the reversible voltage, ohmic overpotential and activation overpotential, the analytical solution for the actual cell output voltage can be calculated by the following equation:

$V=V_{\text {nenrst }}-\eta_{\text {act }}-\eta_{\text {ohm }}$

Note that the mass transport plays an important role not only in the membrane ionic conductivity but also in the reaction kinetics. Hence detailed mass transport inside the cell should be carried out in the upcoming modeling work.

\subsubsection{Multiphase Flow}

In the modeling study, the mass balance equations for the liquid water, $\mathrm{H}_{2}$ and air $\left(\right.$ or $\mathrm{O}_{2}$ ) are solved in the corresponding computational domains. Tables 2 and 3 present the mass balance equation group for liquid water and gas species, respectively. In the mass balance equations for liquid water, 
$C_{\mathrm{GDL} / \mathrm{MPL}, \mathrm{GDL}, \mathrm{a}}^{\mathrm{lq}}\left(\mathrm{mol} \mathrm{m}^{-3}\right)$ represents the molar concentration of liquid water at the interface of GDL and MPL on GDL side of anode and other denominating rules is conducted by the same method. $D_{m, n}^{\mathrm{lq}}$ $\left(m^{2} \mathrm{~s}^{-1}\right)$ means the capillary diffusion coefficient of liquid water. Here the subscript $m, n(m=c h$, GDL, MPL and CL) denotes in the location $m$ in the electrode $n$ ( $n=\mathrm{a}$ and $\mathrm{c}$, a: anode, c: cathode) side, and for instance, GDL, a means in the GDL of anode. The capillary diffusion coefficient $D^{\text {lq }}$ can be obtained with the liquid permeability $\left(K_{l q}, \mathrm{~m}^{2}\right)$ and capillary pressure $\left(p_{c}, \mathrm{~Pa}\right)[30]$ :

$$
\begin{aligned}
& D^{\mathrm{lq}}=-\frac{K_{\mathrm{lq}}}{\mu_{\mathrm{lq}}} \cdot \frac{\mathrm{d} p_{\mathrm{c}}}{\mathrm{d} s_{\mathrm{lq}}} \\
& K_{\mathrm{lq}}=K_{0}{s_{\mathrm{lq}}}^{4}
\end{aligned}
$$

where $\mu_{\mathrm{lq}}$ denotes dynamic viscosity $\left(\mathrm{kg} \mathrm{m}^{-1} \mathrm{~s}^{-1}\right)$ of liquid water. $K_{l q}$ is solved according to the intrinsic permeability of the electrode $\left(K_{0}\right)$ corrected by the local volume fraction of liquid water $\left(s_{l q}\right)$. $p_{c}$ serves as a correlation of surface tension coefficient of liquid water $\left(\sigma_{\mathrm{lq}}, \mathrm{N} \mathrm{m}^{-1}\right)$, hydrophobic property of the porous electrode (contact angle $\theta,{ }^{\circ}$ ), electrode porosity $(\varepsilon), K_{0}$ and $s_{l q}[32,33]$ :

$$
p_{\mathrm{c}}= \begin{cases}\sigma_{\mathrm{lq}} \cos \theta\left(\frac{\varepsilon}{K_{0}}\right)^{0.5}\left[1.42\left(1-s_{\mathrm{lq}}\right)-2.12\left(1-s_{\mathrm{lq}}\right)^{2}+1.26\left(1-s_{\mathrm{lq}}\right)^{3}\right] & \text { if } \theta<90^{\circ} \\
\sigma_{\mathrm{lq}} \cos \theta\left(\frac{\varepsilon}{K_{0}}\right)^{0.5}\left[1.42 s_{\mathrm{lq}}-2.12{s_{\mathrm{lq}}}^{2}+1.26 \mathrm{~s}_{\mathrm{lq}}{ }^{3}\right] & \left(\begin{array}{cc}
1 & 2
\end{array}\right)\end{cases}
$$

$\delta_{\mathrm{GDL}}, \delta_{\mathrm{MPL}}, \delta_{\mathrm{CL}}$ and $\delta_{\mathrm{m}}$ refer to the thicknesses of $\mathrm{GDL}, \mathrm{MPL}, \mathrm{CL}$ and alkaline membrane, respectively. $N_{n}^{\mathrm{lq}}(n=\mathrm{a}$ and c, a:anode, c:cathode) stands for the mass flow rates in the electrode $n$ in the direction perpendicular to the membrane. $M_{\mathrm{H}_{2} \mathrm{O}}\left(0.018 \mathrm{~kg} \mathrm{~mol}^{-1}\right)$ is the molar mass of water. $I\left(\mathrm{~A} \mathrm{~m}^{-2}\right)$ is the operating current density. $n_{\mathrm{d}}$ represents the electro-osmotic drag coefficient and is defined as [34]

$n_{\mathrm{d}}=0.183 \lambda+1.3$

in which $\lambda$ is water content in the alkaline membrane and can be defined based on the water activity (a) the local temperature $(T)$ in the MEA [35]. 


$$
\lambda= \begin{cases}4.908-0.0153 T-(0.205 T-87.596) a & \\ +(0.85 T-313.878) a^{2}-(0.48 T-189.312) a^{3} & \text { if } 0.0<a<1.0 \\ (0.05795-0.00265 a)(T-313.15) & \\ +14.817+1.5915(a-1) & \text { if } 1.0<a<3.0\end{cases}
$$

a considered in this study is calculated based on the saturation of liquid phase and vapor phase:

$$
a=\frac{Y_{\mathrm{vapor}} p^{\mathrm{gas}}}{p_{\mathrm{sat}}}+2 s_{\mathrm{lq}}
$$

$Y_{\text {vapor }}$ is the molar fraction of water vapor in the gas mixtures. $p_{\mathrm{g}}$ and $p_{\text {sat }}(\mathrm{Pa})$ are the pressure of the gas mixture and saturated pressure of the water vapor, respectively.

$\rho_{\mathrm{a}}^{\mathrm{lq}}$ and $\rho_{\mathrm{c}}^{\mathrm{lq}}\left(\mathrm{kg} \mathrm{m}^{-3}\right)$ are the averaged apparent mass density in anode $\mathrm{CL}$ and cathode $\mathrm{CL}$, respectively. $D_{M}\left(\mathrm{~m}^{2} \mathrm{~s}^{-1}\right)$ is the water diffusivity in the alkaline membrane and contingent on the water content in the membrane $(\lambda)$ and the operating temperature [34]:

$$
D_{\mathrm{m}}=\left\{\begin{array}{lr}
(0.0051 \lambda \times T-1.44 \lambda) \times 10^{-10} & \text { if } 0 \leq \lambda<14 \\
\left(-23.2404+4.513 \lambda-0.28926 \lambda^{2}+0.006131 \lambda^{3}\right) \times(T-303.15) \times 10^{-10} \\
+\left[-79.826+17.928 \lambda-1.3329 \lambda^{2}+0.03337 \lambda^{3}\right] \times 10^{-10} & \text { if } 14<\lambda \leq 19 \\
{\left[\left(-41.916+0.00613 \lambda^{3}\right) \times(T-303.15)+8.5139\right] \times 10^{-10}} & \text { if } \lambda>19
\end{array}\right.
$$

$K_{\mathrm{m}}\left(\mathrm{m}^{2}\right)$ represents the intrinsic permeability which acts as an important role in the liquid permeation across the membrane. $p_{\mathrm{a}}^{\mathrm{lq}}$ and $p_{\mathrm{c}}^{\mathrm{lq}}(\mathrm{Pa})$ represent the liquid pressure which can be solved based on the gas pressure and capillary pressure:

$$
p^{\mathrm{lq}}=p^{\mathrm{gas}}-p_{\text {c }}
$$

Note that liquid pressure is solved in continuous distribution in this study. Since the gas pressure is continuous, the capillary should be also continuous through the different porous layers. In consequence, accounting the different physical properties of the neighboring porous layers, such as the contact angle, permeability and porosity, the saturation jump of liquid water is achieved which suggests that there should be a sudden change of liquid water volume fraction at the interface of the 
adjacent porous layers (GDL/MPL and MPL/CL). This is considered more reasonable for the liquid transport between the porous media.

In the mass balance equations of gas species, $C_{m}^{i}$ represents the concentration of the gas species $i$ on the location $m$. Here the superscript $i\left(i=\mathrm{H}_{2}, \mathrm{O}_{2}\right.$ and vapor) means the gas species of $\mathrm{H}_{2}, \mathrm{O}_{2}$ and water vapor, the subscript $m(m=\mathrm{ch} / \mathrm{GDL}, \mathrm{GDL} / \mathrm{MPL}, \mathrm{MPL} / \mathrm{CL}$ and CL/AEM) refers to the location $m$ which points to the interface between the neighboring layers. $D^{i}$ and $D_{j}^{i, \text { eff }}\left(\mathrm{m}^{2} \mathrm{~s}^{-1}\right)(i=$ $\mathrm{H}_{2}, \mathrm{O}_{2}$ and vapor) are the intrinsic diffusivity and effective diffusivity of species $i$ in the electrode $j$ (GDL, MPL and CL). $A_{C}\left(\mathrm{~m}^{2}\right)$ signifies the active area inside the cell. $d_{\mathrm{h}}, W$ and $L(\mathrm{~m})$ represent the hydraulic diameter, width and length of the flow channel. In the modeling work, the mass convection is not directly taken into consideration in the mass conservation equations in the GDL, MPL and CL because it performs more significantly in the mass flow between flow channel and GDL. For simplification, the Sherwood number $(S h)$ is used for quantify the mass transport rate from flow channel to GDL and can be defined as a non-dimensional number:

$$
S h=\frac{k^{\prime} L}{D_{A B}}
$$

in which $k^{\prime}\left(\mathrm{m} \mathrm{s}^{-1}\right)$ is transfer coefficient, $L(\mathrm{~m})$ is the feature size of the transfer path, $D_{A B}\left(\mathrm{~m}^{2} \mathrm{~s}^{-1}\right)$ is the feature coefficient of solute A inside solvent $B$. 
Table 2. Mass balance equations for liquid water.

\begin{tabular}{|c|c|c|}
\hline Species & Mass balance equation & Solved in \\
\hline \multirow{9}{*}{$\begin{array}{l}\text { Liquid } \\
\text { water }\end{array}$} & $\frac{\left(C_{\mathrm{GDL} / \mathrm{MPL}, \mathrm{GDL}, \mathrm{a}}^{\mathrm{lq}}-C_{\mathrm{ch} / \mathrm{GDL}, \mathrm{GDL}, \mathrm{a}}^{\mathrm{lq}}\right) D_{\mathrm{GDL}, \mathrm{a}}^{\mathrm{lq}}}{\delta_{\mathrm{GDL}}}=N_{\mathrm{a}}^{\mathrm{lq}}$ & $\begin{array}{l}\text { Anode } \\
\text { GDL }\end{array}$ \\
\hline & $\frac{\left(C_{\mathrm{MPL} / \mathrm{CL}, \mathrm{MPL}, \mathrm{a}}^{\mathrm{lq}}-C_{\mathrm{GDL} / \mathrm{MPL}, \mathrm{MPL}, \mathrm{a}}^{\mathrm{lq}}\right) D_{\mathrm{MPL}, \mathrm{a}}^{\mathrm{lq}}}{\delta_{\mathrm{MPL}}}=N_{\mathrm{a}}^{\mathrm{lq}}$ & $\begin{array}{l}\text { Anode } \\
\text { MPL }\end{array}$ \\
\hline & $\begin{array}{l}\frac{M_{\mathrm{H}_{2} \mathrm{O}} I}{F \delta_{\mathrm{CL}}}+\frac{n_{\mathrm{d}} M_{\mathrm{H}_{2} \mathrm{O}} I}{F \delta_{\mathrm{CL}}}=\frac{D_{\mathrm{m}}\left(\rho_{\mathrm{a}}^{\mathrm{lq}}-\rho_{\mathrm{c}}^{\mathrm{lq}}\right)}{\delta_{\mathrm{m}} \delta_{\mathrm{CL}}}+\frac{\rho_{\mathrm{lq}} K_{\mathrm{m}}\left(p_{\mathrm{a}}^{\mathrm{lq}}-p_{\mathrm{c}}^{\mathrm{lq}}\right)}{\mu_{\mathrm{lq}} \delta_{\mathrm{m}} \delta_{\mathrm{CL}}}+\frac{N_{\mathrm{a}}^{\mathrm{lq}} M_{\mathrm{H}_{2} \mathrm{O}}}{\delta_{\mathrm{CL}}} \\
\underline{\left(C_{\mathrm{CL} / \mathrm{AEM}, \mathrm{a}}^{\mathrm{lq}}-C_{\mathrm{CL} / \mathrm{MPL}, \mathrm{CL}, \mathrm{a}}\right) D_{\mathrm{CL}, \mathrm{a}}^{\mathrm{lq}}}=N^{\mathrm{lq}}\end{array}$ & Anode CL \\
\hline & $\delta_{\mathrm{CL}}$ & \\
\hline & 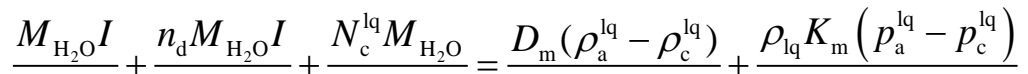 & \\
\hline & 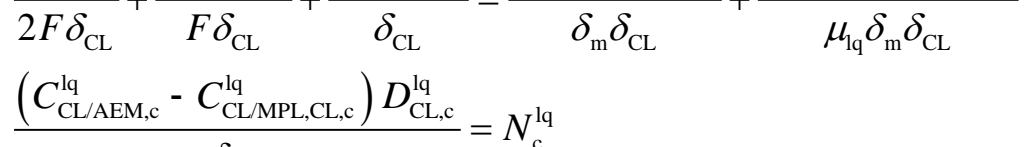 & $\begin{array}{l}\text { Cathode } \\
\text { CL }\end{array}$ \\
\hline & $\delta_{\mathrm{CL}}$ & \\
\hline & $\frac{\left(C_{\mathrm{MPL} / \mathrm{LL}, \mathrm{MPL}, \mathrm{c}}^{\mathrm{lq}}-C_{\mathrm{GDL} / \mathrm{MPL}, \mathrm{MPL}, \mathrm{c}}^{\mathrm{lq}}\right) D_{\mathrm{MPL}, \mathrm{c}}^{\mathrm{lq}}}{\delta_{\mathrm{MPL}}}=N_{\mathrm{c}}^{\mathrm{lq}}$ & $\begin{array}{l}\text { Cathode } \\
\text { CL }\end{array}$ \\
\hline & $\frac{\left(C_{\mathrm{GDL} / \mathrm{MPL}, \mathrm{GDL}, \mathrm{c}}^{\mathrm{lq}}-C_{\mathrm{ch} / \mathrm{GDL}, \mathrm{GDL}, \mathrm{c}}^{\mathrm{lq}}\right) D_{\mathrm{GDL}, \mathrm{c}}^{\mathrm{lq}}}{\delta_{\mathrm{GDL}}}=N_{\mathrm{c}}^{\mathrm{lq}}$ & $\begin{array}{l}\text { Cathode } \\
\text { GDL }\end{array}$ \\
\hline
\end{tabular}


Table 3. Mass balance equations for gas species.

\begin{tabular}{|c|c|c|}
\hline Species & Mass balance equation & Solved in \\
\hline \multirow{8}{*}{ Hydrogen } & $\underline{\left(C_{\mathrm{ch}}^{\mathrm{H}_{2}}-C_{\mathrm{ch} / \mathrm{GDL}}^{\mathrm{H}_{2}}\right) D^{\mathrm{H}_{2}} A_{\mathrm{c}} S h}=\underline{I}$ & \multirow{2}{*}{ Anode flow channel } \\
\hline & $d_{\mathrm{h}} W L$ & \\
\hline & $\underline{\left(C_{\mathrm{ch} / \mathrm{GDL}}^{\mathrm{H}_{2}}-C_{\mathrm{GDL} / \mathrm{MPL}}^{\mathrm{H}_{2}}\right) D_{\mathrm{GDL}}^{\mathrm{H}_{2}, \text { eff }}}=\underline{I}$ & \multirow{2}{*}{ Anode GDL } \\
\hline & $\delta_{\mathrm{GDL}}$ & \\
\hline & $\left(C_{\mathrm{GDL} / \mathrm{MPL}}^{\mathrm{H}_{2}}-C_{\mathrm{MPL} / \mathrm{CL}}^{\mathrm{H}_{2}}\right) D_{\mathrm{MPL}}^{\mathrm{H}_{2}, \mathrm{eff}}$ & \multirow{2}{*}{ Anode MPL } \\
\hline & $\delta_{\mathrm{MPL}}$ & \\
\hline & $\underline{\left(C_{\mathrm{MPL} / \mathrm{CL}}^{\mathrm{H}_{2}}-C_{\mathrm{CL} / \mathrm{AEM}}^{\mathrm{H}_{2}}\right) D_{\mathrm{CL}}^{\mathrm{H}_{2}, \mathrm{eff}}}=\underline{I}$ & \multirow{2}{*}{ Anode CL } \\
\hline & $\delta_{\mathrm{CL}}$ & \\
\hline \multirow{8}{*}{ Oxygen } & $\left(C_{\mathrm{ch}}^{\mathrm{O}_{2}}-\mathrm{C}_{\mathrm{ch} / \mathrm{GDL}}^{\mathrm{O}_{2}}\right) D^{\mathrm{O}_{2}} A_{\mathrm{c}} S h=\underline{\mathrm{I}}$ & \multirow{2}{*}{$\begin{array}{l}\text { Cathode flow } \\
\text { channel }\end{array}$} \\
\hline & $d_{\mathrm{h}} W L$ & \\
\hline & $\underline{\left(\mathrm{C}_{\mathrm{ch} / \mathrm{GDL}}^{\mathrm{O}_{2}}-C_{\mathrm{GDL} / \mathrm{MPL}}^{\mathrm{O}_{2}}\right) D_{\mathrm{GDL}}^{\mathrm{O}_{2}, \mathrm{eff}}}$ & \multirow{2}{*}{ Cathode GDL } \\
\hline & $\delta_{\mathrm{GDL}}$ & \\
\hline & $\underline{\left(C_{\mathrm{GDL} / \mathrm{MPL}}^{\mathrm{O}_{2}}-C_{\mathrm{MPL} / \mathrm{CL}}^{\mathrm{O}_{2}}\right) D_{\mathrm{MPL}}^{\mathrm{O}_{2}, \text { eff }}}$ & \multirow{2}{*}{ Cathode MPL } \\
\hline & $\delta_{\mathrm{MPL}}$ & \\
\hline & $\underline{\left(C_{\mathrm{MPL} / \mathrm{CL}}^{\mathrm{O}_{2}}-C_{\mathrm{AEM} / \mathrm{CL}}^{\mathrm{O}_{2}}\right) D_{\mathrm{CL}}^{\mathrm{O}_{2}, \text { eff }}}=\underline{I}$ & \multirow{2}{*}{ Cathode CL } \\
\hline & $\delta_{\mathrm{CL}}$ & \\
\hline \multirow{8}{*}{ Water vapor } & $\underline{\left(C_{\mathrm{ch}}^{\mathrm{vapor}}-C_{\mathrm{ch} / \mathrm{GDL}}^{\mathrm{vapor}}\right) D^{\mathrm{vapor}} A_{c} S h}=\frac{I}{I}$ & \multirow{2}{*}{$\begin{array}{l}\text { Cathode flow } \\
\text { channel }\end{array}$} \\
\hline & $d_{\mathrm{h}} W L$ & \\
\hline & $\underline{\left(\mathrm{C}_{\mathrm{ch} / \mathrm{GDL}}^{\mathrm{vapor}}-C_{\mathrm{GDL} / \mathrm{MPL}}^{\mathrm{vapor}}\right) D_{\mathrm{GDL}}^{\text {vapor,eff }}}$ & \multirow{2}{*}{ Cathode GDL } \\
\hline & $\delta_{\mathrm{GDL}}$ & \\
\hline & $\underline{\left(C_{\mathrm{GDL} / \mathrm{MPL}}^{\mathrm{vapor}}-\mathrm{C}_{\mathrm{MPL} / \mathrm{LL}}^{\mathrm{vapor}}\right) D_{\mathrm{MPL}}^{\mathrm{vapor}, \mathrm{eff}}}$ & \multirow{2}{*}{ Cathode MPL } \\
\hline & $\delta_{\mathrm{MPL}}$ & \\
\hline & $\underline{\left(C_{\mathrm{MPL} / \mathrm{CL}}^{\mathrm{vapor}}-C_{\mathrm{AEM} / \mathrm{CL}}^{\mathrm{vapor}}\right) D_{\mathrm{CL}}^{\mathrm{vapor}, \text { eff }}}$ & \multirow{2}{*}{ Cathode CL } \\
\hline & $\delta_{\mathrm{CL}}$ & \\
\hline
\end{tabular}

Before simulation, the modeling formulation, the cell design parameters and transport properties have been modified accordingly using the experimental data to account for the mass transport behavior inside the AEM fuel cell and further discuss the resulting performance of the testing AEM fuel cell. Table 4 gives the related transport properties and correlations inside the AEM fuel cell. 
Table 4. Transport property.

\begin{tabular}{|c|c|c|}
\hline Parameters & Correlation/value & Unit \\
\hline Hydrogen dynamic viscosity & $\mu_{\mathrm{H}_{2}}=3.205 \times 10^{-3}(T / 293.85)^{1.5}(T+72)^{-1.0}$ & $\mathrm{~kg} \mathrm{~m}^{-1} \mathrm{~s}^{-1}$ \\
\hline Oxygen dynamic viscosity & $\mu_{\mathrm{O}_{2}}=8.46 \times 10^{-3}(T / 293.85)^{1.5}(T+127)^{-1.0}$ & $\mathrm{~kg} \mathrm{~m}^{-1} \mathrm{~s}^{-1}$ \\
\hline Water vapor dynamic viscosity & $\mu_{\text {vap }}=7.512 \times 10^{-3}(T / 291.15)^{1.5}(T+120)^{-1.0}$ & $\mathrm{~kg} \mathrm{~m}^{-1} \mathrm{~s}^{-1}$ \\
\hline Liquid water dynamic viscosity & $\mu_{\mathrm{lq}}=2.414 \times 10^{-5} \times 10^{247.8 /(T-140)}$ & $\mathrm{kg} \mathrm{m}^{-1} \mathrm{~s}^{-1}$ \\
\hline Hydrogen diffusivity in anode & $D^{\mathrm{H}_{2}}=1.055 \times 10^{-4}(T / 333.15)^{1.5}(101325 / P)^{1.0}$ & $m^{2} s^{-1}$ \\
\hline Water vapor diffusivity in anode & $D^{\mathrm{vap}, \mathrm{a}}=1.055 \times 10^{-4}(T / 333.15)^{1.5}(101325 / P)^{1.0}$ & $m^{2} s^{-1}$ \\
\hline Oxygen diffusivity in cathode & $D^{\mathrm{O}_{2}}=2.652 \times 10^{-5}(T / 333.15)^{1.5}(101325 / P)^{1.0}$ & $m^{2} s^{-1}$ \\
\hline Water vapor diffusivity in cathode & $D^{\mathrm{vap}, \mathrm{c}}=2.982 \times 10^{-5}(T / 333.15)^{1.5}(101325 / P)^{1.0}$ & $\mathrm{~m}^{2} \mathrm{~s}^{-1}$ \\
\hline $\begin{array}{l}\text { Effective diffusivity of the gas i } \\
\left(\mathrm{H}_{2}, \mathrm{O}_{2}, \text { vap) in the electrode } \mathrm{j}\right. \\
\text { (GDL,MPL,CL) }\end{array}$ & $D_{j}^{i, \text { eff }}=D_{i} \varepsilon_{j}^{1.5}\left(1-s_{\mathrm{lq}}\right)^{1.5}$ & $m^{2} s^{-1}$ \\
\hline Liquid water density & $\rho_{\mathrm{lq}}=1000$ & $\mathrm{~kg} \mathrm{~m}^{-3}$ \\
\hline Intrinsic permeability of GDL & $K_{\mathrm{GDL}}=2.0 \times 10^{-12}$ & $\mathrm{~m}^{2}$ \\
\hline Intrinsic permeability of MPL & $K_{\mathrm{MPL}}=5.0 \times 10^{-13}$ & $\mathrm{~m}^{2}$ \\
\hline Intrinsic permeability of CL & $K_{\mathrm{CL}}=1.0 \times 10^{-13}$ & $\mathrm{~m}^{2}$ \\
\hline Intrinsic permeability of membrane & $K_{\mathrm{m}}=7.0 \times 10^{-19}$ & $\mathrm{~m}^{2}$ \\
\hline Saturated vapor pressure & $\begin{array}{l}\log _{10}\left(\frac{P_{\text {sat }}}{101325}\right)=-2.1794+0.02953(T-273.15) \\
-9.1837 \times 10^{5}(T-273.15)^{2}+1.4454 \times 10^{-7}(T-273.15)^{3}\end{array}$ & $\mathrm{~Pa}$ \\
\hline $\begin{array}{l}\text { Liquid water surface tension } \\
\text { coefficient } \\
\text { Transfer coefficients }\end{array}$ & $\begin{array}{l}\sigma_{\mathrm{lq}}=-0.0001676 \times \mathrm{T}+0.1218 \\
\alpha=0.5\end{array}$ & $\mathrm{~N} \mathrm{~m}^{-1}$ \\
\hline
\end{tabular}

\section{Results and Discussion}

This section presents the experimental operating performance of AEM fuel cell under different operating pressures for anode and cathode and compares the modeling prediction and experimental data. The AEM fuel cells with $\mathrm{H}_{2} /$ air and $\mathrm{H}_{2} / \mathrm{O}_{2}$ as feed gases are all tested in this study. In the experimental tests, at least three trials are conducted for each operating condition to achieve the reliability of the experimental results. The operating behaviors are rigorously explained based on the analytical modeling results and in-situ EIS data. As mentioned previously, one important issue of the previous work in the literature is that the models for AEM fuel cell need to be validated more comprehensively to characterize the transport mechanism precisely, not just focusing on the $I-V$ curve validation [22]. Therefore, prior to the modeling analysis in this study, the modeling validation on both the polarization characteristics and ohmic overpotential evolution has been done to maintain a reasonable modeling formulation. General discussions have been 
rounded explicitly into the following section and recommendations and concerns for water management strategy have been also addressed.

\subsection{Operating behavior of $\mathrm{H}_{2} /$ air AEM fuel cell}

Firstly, the operating characteristics of an AEM fuel cell fed by $\mathrm{H}_{2} /$ air have been experimentally tested under various back pressures for anode and cathode, which is displayed in Figure 2(a). AOCO is used to represent the operation condition with back pressure of $0 \mathrm{kPa}$ and $0 \mathrm{kPa}$ for anode and cathode, respectively; by this analogy, A50C50 (anode: $50 \mathrm{kPa}$, cathode: $50 \mathrm{kPa}$ ), A70C50 (anode: $70 \mathrm{kPa}$, cathode: $50 \mathrm{kPa}$ ) and $\mathrm{A} 100 \mathrm{C} 50$ (anode: $100 \mathrm{kPa}$, cathode: $50 \mathrm{kPa}$ ) are all used for easy description of various operating back pressures.

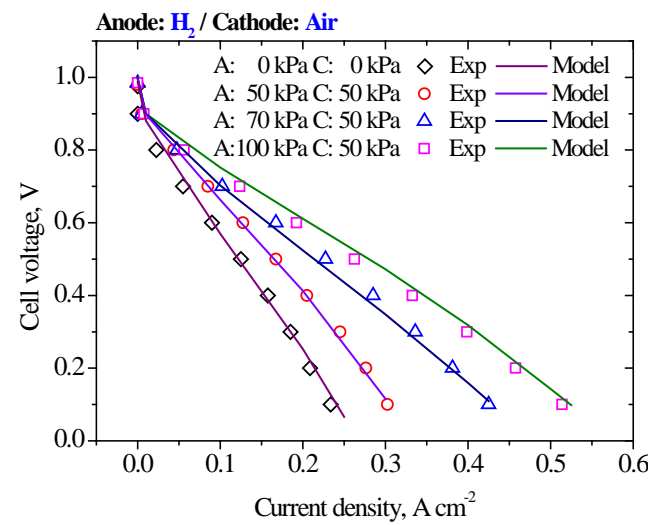

(a)

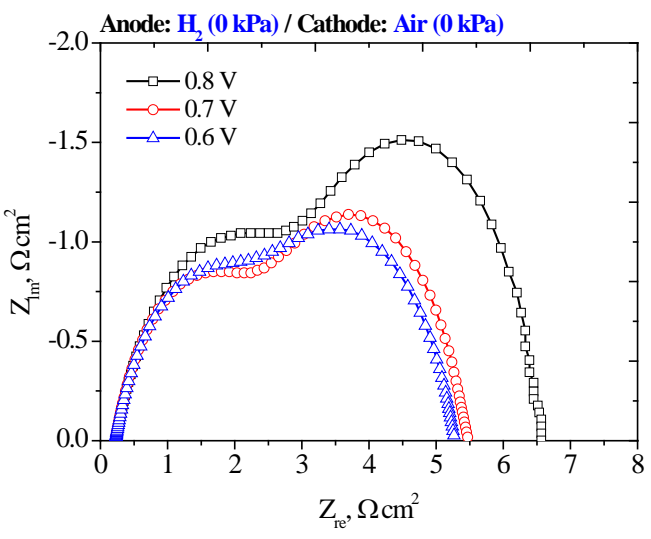

(c)

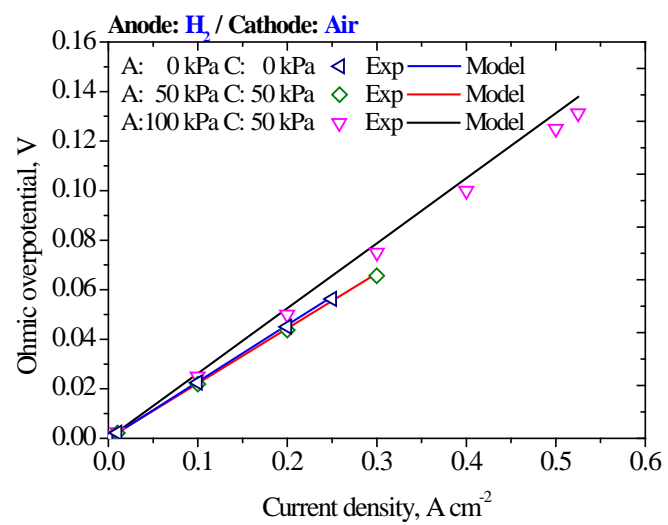

(b)

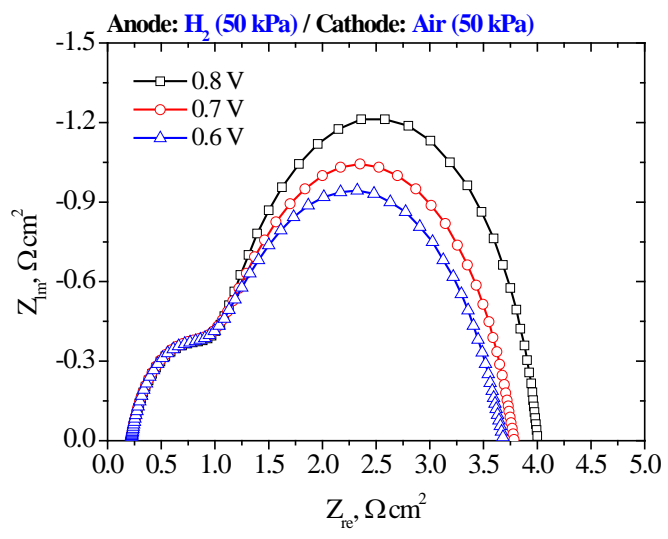

(d) 


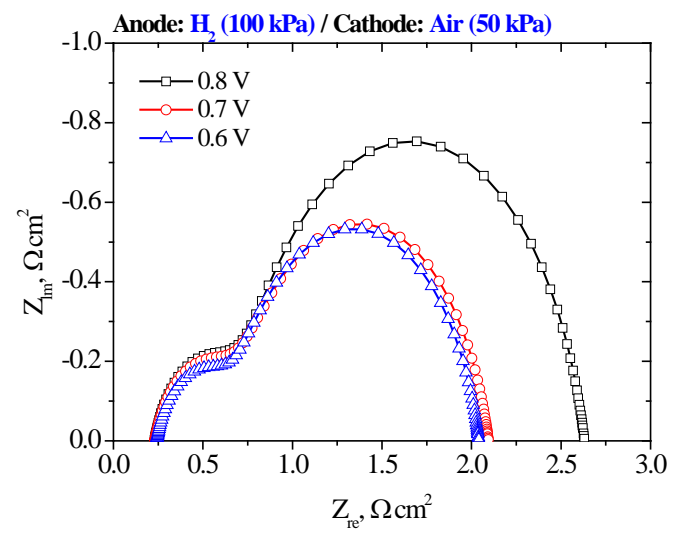

(e)

Figure 2. Comparison of (a) polarization curve and (b) ohmic overpotential between the present model predictions and experimental test data with air as cathode inlet gas, and effect of polarization potential on impedance plots for AEM fuel cell with various back pressures for anode and cathode: (c) anode: $0 \mathrm{kPa}$, cathode: $0 \mathrm{kPa}$; (d) anode: $50 \mathrm{kPa}$, cathode: $50 \mathrm{kPa}$ and (e) anode: $100 \mathrm{kPa}$, cathode: $50 \mathrm{kPa}$, with air as cathode inlet gas. Applied DC potential: $0.8 \mathrm{~V}, 0.7 \mathrm{~V}$ and $0.6 \mathrm{~V}$.

The results indicate that increasing the operating back pressure for the electrodes greatly improves the cell output, being capable of a higher limiting current density. Figure 2(b) depicts the variation of the ohmic overpotential during the fuel cell operation, which is plotted against current density according to the in-situ EIS results recorded on the overall fuel cell components, as shown in Figure 2(c), (d) and (e). It indicates that the ohmic resistance remains relatively stable as varying the operating back pressure. It is obvious that the averaged water amount in the MEA does not change too much in the four cases as drawn in Figure 3(a) (liquid water distribution) which lies behind the stable ohmic resistance of alkaline membrane, as well as the overall ohmic overpotential in Figure 2(b). Strictly, A0C0 and A50C50 cases do not much affect the water transport inside the cell, as well as the membrane ionic conductivity, therefore similar liquid water distribution can be observed in Figure 3(a). However, through further raising the back pressure up to $100 \mathrm{kPa}$ for anode, the liquid water saturation is greatly reduced in anode and slightly increased in cathode, generating reduced averaged water content in the MEA and subdued membrane ionic conductivity in A100C50 case (Figure 2(b)). Moreover, note that the liquid water saturation jump at the interface of the neighboring porous layers is also achieved in this modeling work, as depicted in Figure 3(a) and matches the trends in literature. 


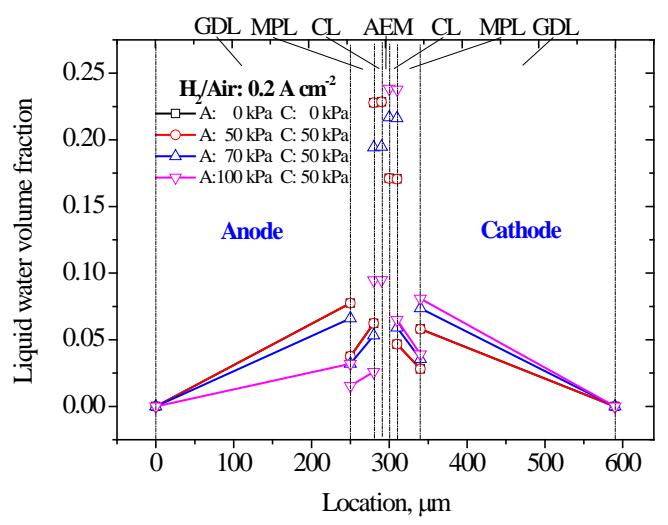

(a)

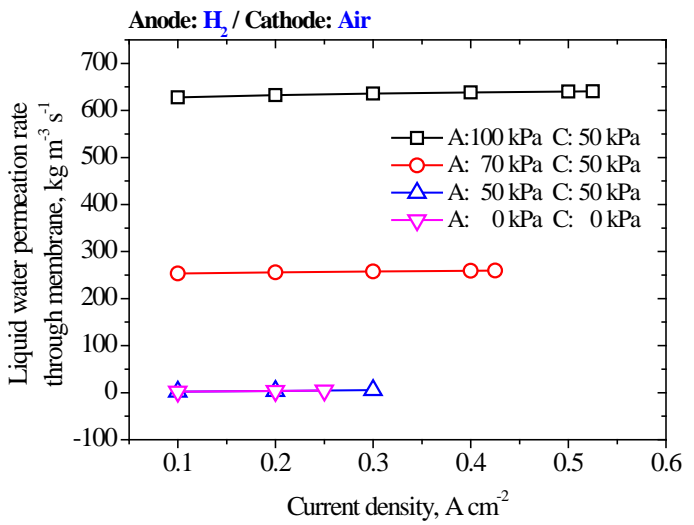

(b)

Figure 3. (a) Liquid water distribution in the electrodes and (b) liquid water permeation through the A901 alkaline membrane with air as cathode inlet gas.

The weak variation of ohmic resisntance suggests that the reduced activation overpotential, as well as enhanced electrochemical kinetics, plays the leading role in the variation of the cell performance. The analytical modeling work is used to gain a deeper knowledge with the detailed mass transfer inside the fuel cell. Understanding these internal mass transport mechanism and losses provides insight into the detailed physics behind the variation of cell output. Through comparing AOCO and A50C50 cases, the optimized thermodynamic reversible voltage and sufficient reactant supply rate should be responsible for the output improvement of A50C50 case. On the other hand, the experimental results in $\mathrm{A} 0 \mathrm{C} 0, \mathrm{~A} 70 \mathrm{C} 50$ and $\mathrm{A} 100 \mathrm{C} 50$ cases reveal that the operating pressure gradient from anode to cathode may further lead to better cell output. By inspecting the modeling simulation, the significant liquid permeation from anode to cathode is beneficial for the operating capability. It should be noted that liquid permeation through the membrane was largely ignored in literature, as the effect is weak at normal operating pressure (around $1 \mathrm{~atm}$ ) $[20,21]$. However, regarding the direct alcohols (liquid fuel) AEM fuel cell and $\mathrm{H}_{2} \mathrm{AEM}$ fuel cell operating at various feeding pressures, the significant hydraulic pressure gradient between anode and cathode suggests that the liquid permeation must be considered for the water transport through the membrane [36]. Figure 3(b) shows the liquid permeation rate through the alkaline membrane from anode to cathode. By examination of the liquid permeation data, larger operating pressure gradient brings about larger liquid pressure gradient, further contributing to more prominent liquid permeation towards cathode CL. Water is generated in anode CL, possibly generating the anode 
flooding issue, while consumed in cathode CL which brings out an intrinsic dehydrated condition inside cathode, which was also mentioned by Omasta et al. in their experimental work [15]. Liquid permeation from anode to cathode theoretically mitigates the anode flooding problem and cathode water scarcity, giving rise to better catalyst utilization in anode CL and sufficient reactant supply for cathode reaction, and thus faster reaction rate for both anode and cathode. The modeled enhanced reaction kinetics for both anode and cathode is also prone by comparing the developing trends for impedance plots displayed in Figure 2(c), (d) and (e). Furthermore, it should be addressed that the integrated effect of pressure difference between anode and cathode should be more notable at high operating current densities attributing to more significant liquid permeation through the membrane and possible better water balance between anode and cathode.

Figure 4 overlays the water transport variable data through alkaline membrane including the water back diffusion from anode to cathode, electro-osmotic drag effect from cathode to anode and liquid water permeation through alkaline membrane. Under the normal operating condition of AOCO as presented in Figure 4(a), the water back diffusion is intrinsically from anode to cathode due to the water generation and consumption in anode and cathode $\mathrm{CL}$, respectively; electro-osmotic drag effect should be away from cathode; and direction of the liquid water permeation is contingent on liquid pressure distributed across the alkaline membrane. However, modeling results displayed in Figure 4(b) describes an interesting water transport behavior through the membrane. The model obtained value of the water back diffusion rate varies from negative to positive gradually with the current density increasing, which suggests that there exists a turning point of water back diffusion direction. At lower current densities, water back diffusion is observed to be weaker through holding a smaller water concentration difference between anode and cathode mainly because of the limited water generation in anode CL. It is obvious that the liquid permeation is more significant for the A70C50 case, theoretically bringing about liquid water concentration in cathode CL being higher than the anode side, which reasonably leading to the water back diffusion turning towards anode. This is opposite to the trend in A0CO case. At higher current densities, more water is produced and accumulated in anode CL. This leads ultimately to the highest water concentration remaining inside anode $C L$ in the electrode components, which reverses the water flow direction of back diffusion. By 
further raising the operating pressure in anode as can be seen in Figure 4(c), the modeling result in A100C50 case provides further proof of this possible reversion of water back diffusion.

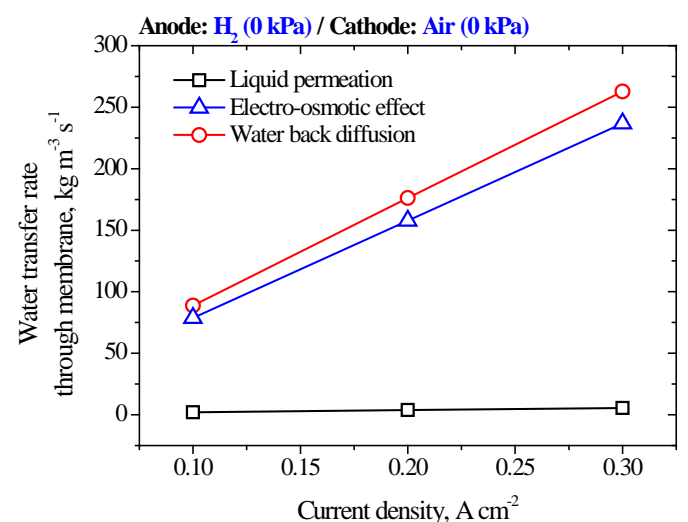

(a)

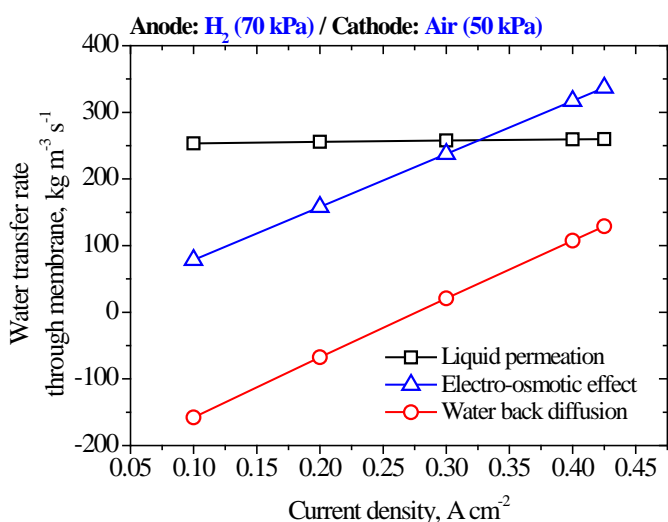

(b)

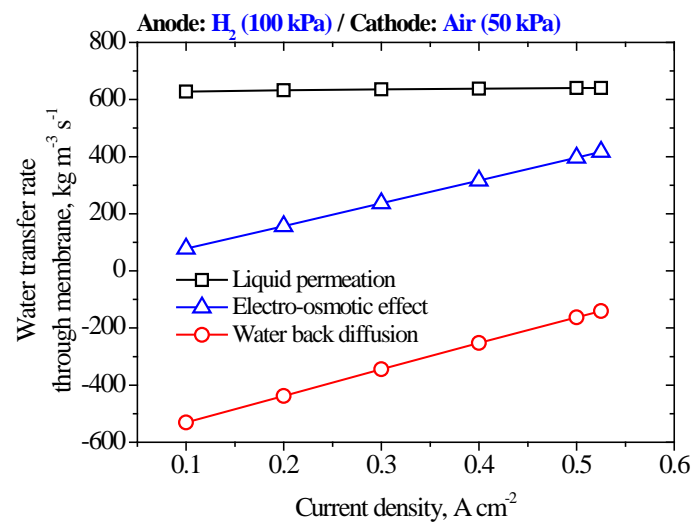

(c)

Figure 4. Water transfer rates through the A901 alkaline membrane with various back pressures of anode and cathode: (a) anode: $0 \mathrm{kPa}$, cathode: $0 \mathrm{kPa}$; (b) anode: $70 \mathrm{kPa}$, cathode: $50 \mathrm{kPa}$ and (c) anode: $100 \mathrm{kPa}$, cathode: $50 \mathrm{kPa}$, with air as cathode inlet gas.

These results give a typical baseline of the operational capability of AEM fuel cell under various back pressures, which offers an alternative means to achieve a better water balance in an AEM fuel cell and enhanced fuel cell output capability.

\subsection{Operating behavior of $\mathrm{H}_{2} / \mathrm{O}_{2}$ AEM fuel cell}

To advance the cell output capabilities, the operation of AEM fuel cell flowed by $\mathrm{H}_{2} / \mathrm{O}_{2}$ are experimentally tested and modeled. In this section, three typical operating back pressures, A0C0 (anode: $0 \mathrm{kPa}$, cathode: $0 \mathrm{kPa}$ ), A50C50 (anode: $50 \mathrm{kPa}$, cathode: $50 \mathrm{kPa}$ ) and A100C50 (anode: $100 \mathrm{kPa}$, cathode: $50 \mathrm{kPa}$ ) are selected representatively for identifying the operating response. 
The resulting experimental and modeling polarization characteristics of a $\mathrm{H}_{2} / \mathrm{O}_{2}$ AEM fuel cell in the cases of A0C0, A50C50 and A100C50 are demonstrated in Figure 5(a). The fuel cell output performance is considered to be comparable to the previous experimental work in the literature $[16,37]$. The modeling results reach a reasonable agreement with the experimental data, as indicated in Figure 5(a) and (b). It is observed that the $\mathrm{H}_{2} / \mathrm{O}_{2} \mathrm{AEM}$ fuel cell performs superior to the $\mathrm{H}_{2} /$ air AEM fuel cell because of being capable of higher limiting current density and maximum power density. Figure $5(b)$ indicates similar variation of ohmic overpotential to the $\mathrm{H}_{2} /$ air cases, yielding sluggish variation under the three operating pressure cases which is displayed utilizing the EIS method in Figure 6.

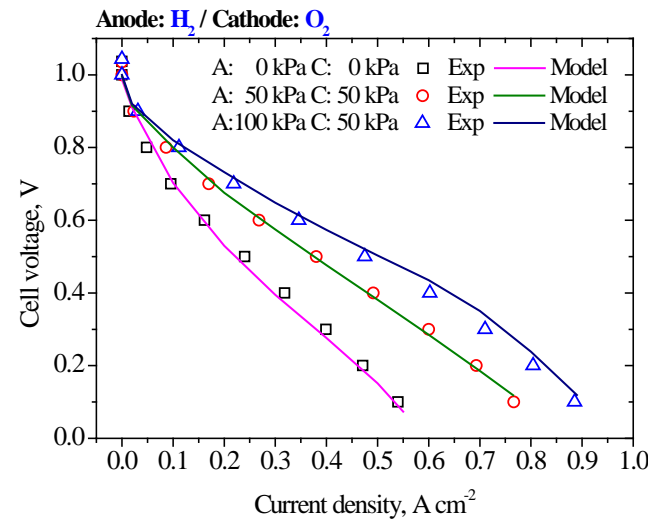

(a)

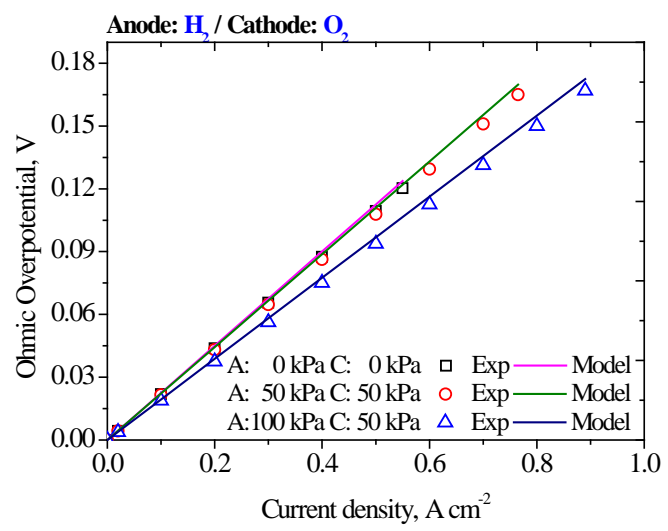

(b)

Figure 5. Comparison of (a) polarization curve and (b) ohmic overpotential between the present model predictions and experimental test data with $\mathrm{O}_{2}$ as cathode inlet gas.



(a)

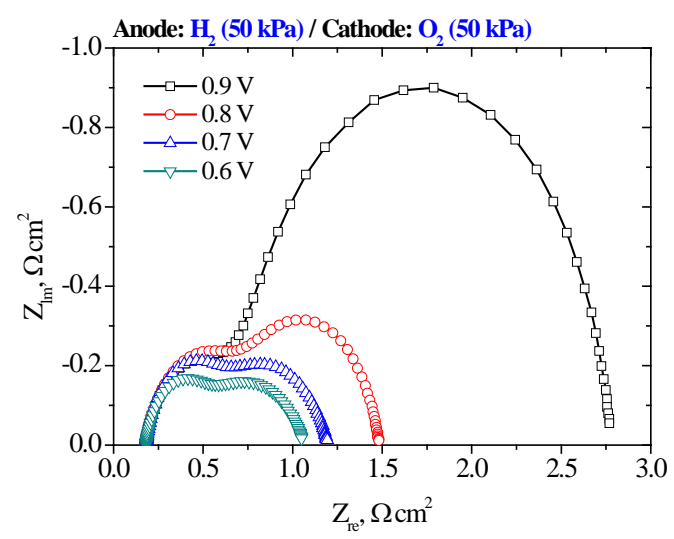

(b) 


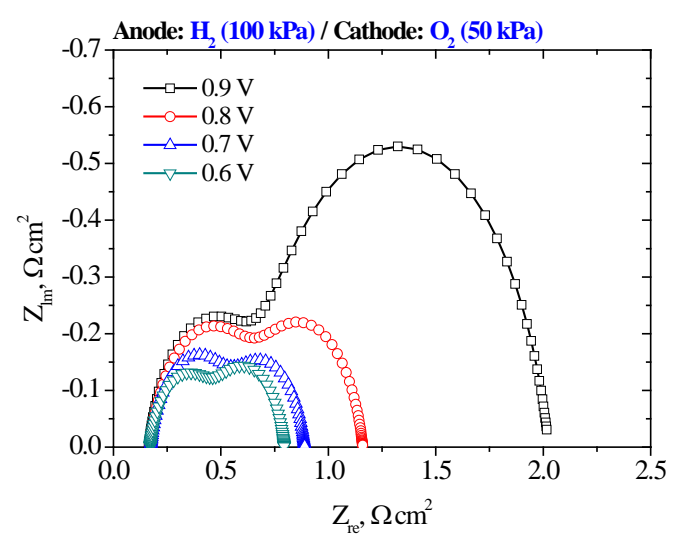

(c)

Figure 6. Effect of polarization potential on impedance plots for AEM fuel cell with various back pressures for anode and cathode: (a) anode: $0 \mathrm{kPa}$, cathode: $0 \mathrm{kPa}$; (b) anode: $50 \mathrm{kPa}$, cathode: 50 $\mathrm{kPa}$ and (c) anode: $100 \mathrm{kPa}$, cathode: $50 \mathrm{kPa}$, with $\mathrm{O}_{2}$ as cathode inlet gas. Applied DC potential: $0.9 \mathrm{~V}, 0.8 \mathrm{~V}, 0.7 \mathrm{~V}$ and $0.6 \mathrm{~V}$.

Figure 7 shows the significant liquid permeation in A100C50 case and how the liquid water distribution performs as put in for pressure gradient of $50 \mathrm{kPa}$ from anode to cathode. Owing to the water consumption in cathode semi-reaction, the impact of reaction kinetics on the activation overpotential highlights the importance of excess water accommodation for the cathode to facilitate faster electrochemical reaction rate. Comparing the amount of water transport rates depicted in Figure 8(a), (b) and (c), similar reversion of water back diffusion is also produced with $50 \mathrm{kPa}$ pressure difference which is guided by the noteworthy liquid permeation.

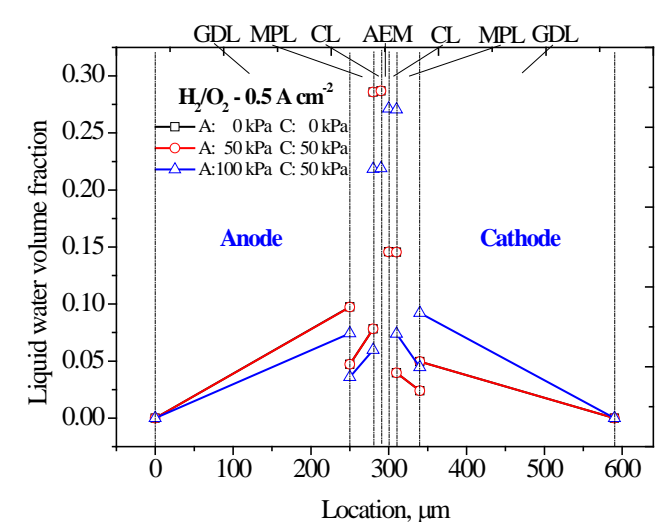

(a)

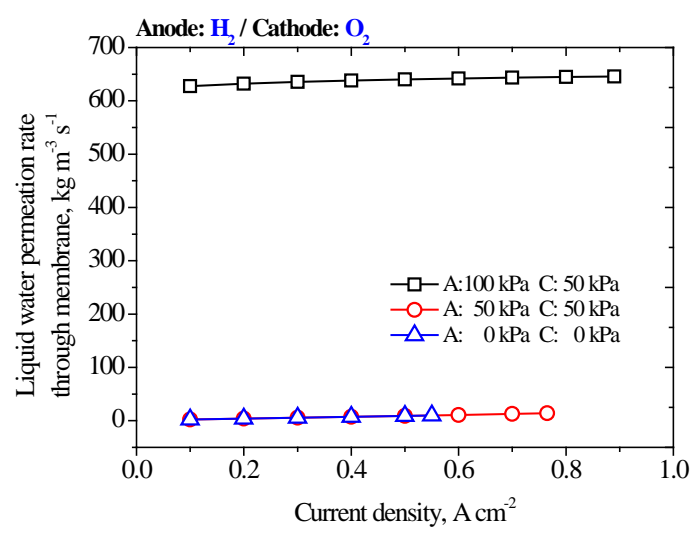

(b)

Figure 7. (a) Liquid water distribution in the electrodes and (b) liquid water permeation through the A901 alkaline membrane with $\mathrm{O}_{2}$ as cathode inlet gas. 


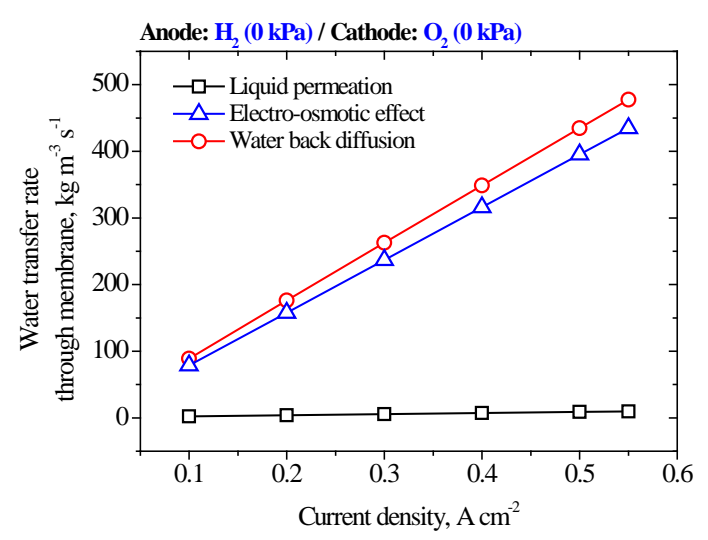

(a)

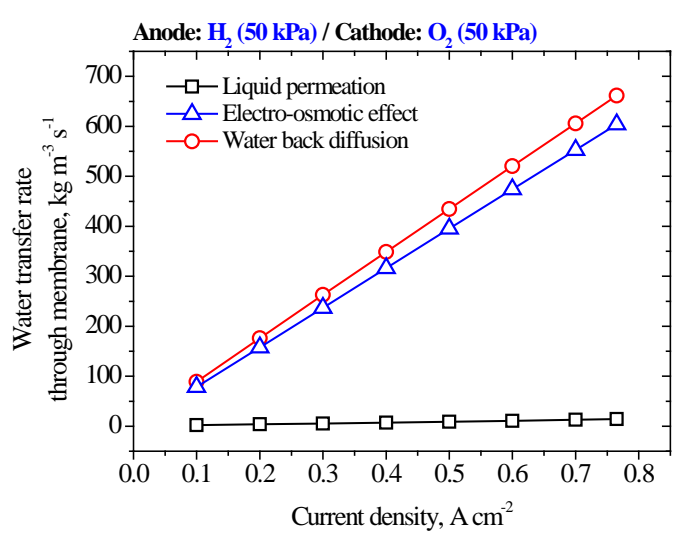

(b)

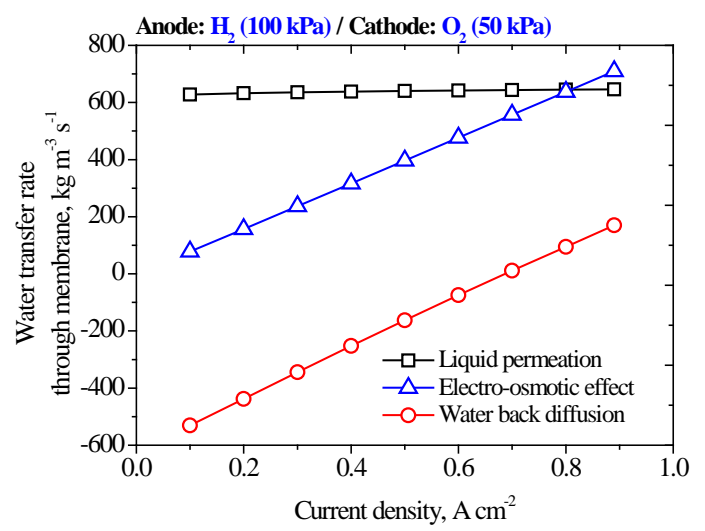

(c)

Figure 8. Water transfer rates through the A901 alkaline membrane with various back pressures for anode and cathode: (a) anode: $0 \mathrm{kPa}$, cathode: $0 \mathrm{kPa}$; (b) anode: $50 \mathrm{kPa}$, cathode: $50 \mathrm{kPa}$ and (c) anode: $100 \mathrm{kPa}$, cathode: $50 \mathrm{kPa}$, with $\mathrm{O}_{2}$ as cathode inlet gas.

Moreover, it can be concluded and noted that: (1) Reasonable operating pressure gradient and thus sufficient liquid permeation from anode to cathode brings benefits for the water balance between anode and cathode, such as mitigating the anode flooding issue and cathode water shortage. This reasonably keeps consistent with the published experimental study conducted by Oshiba et al., in which water transport analysis was experimentally carried out and suppression of anode flooding issue was achieved through promoting the liquid permeation from anode to cathode using thin alkaline membrane and increasing the anode flow rate [16]. (2) Maintaining higher operating pressure at cathode will surely contribute to worse water balance between anode and cathode, as well as the slower electrochemical kinetics for both anode and cathode. (3) As for the cathode, the operating performance is mainly determined by the balance of water supplement for the reaction and water removal ability. Therefore, the water permeation from the anode should be recognized as 
a double-edged sword for the cathode performance. Regarding the AEM fuel cell, water generation and consumption coexists simultaneously inside the cell, serving entirely different from the well-known PEM fuel cell, hence proper pressure managing strategies which actually relies upon the cell design and operating parameters is viewed to be more serious for the water balance maintenance. Also importantly, higher operating pressure may lead to more significant pumping power loss either through the flow channel or the overall fuel cell system. The pros and cons are still required to be further investigated and weighed.

\section{Conclusion}

In this study, in-situ experimental tests, impedance analysis based on in-situ EIS method and analytical modeling on the AEM fuel cell containing A901 alkaline membrane have been implemented to comprehensively explore the operational macro-performance and multiphase transport behavior inside the cell under various operating pressures. The modeling results reach a reasonable agreement with both the experimental polarization and ohmic overpotential data. The experimental results indicate that the cell capability is persistently improved by pulling up the operating pressures and enlarging the pressure gradient from anode to cathode. The ameliorative reaction kinetics should be responsible for the performance improvement. Based on the validated modeling work, the liquid water permeation from anode to cathode performs the major factor affecting the cell performance and leading the water transport behavior through the membrane through maintaining large liquid pressure gradient across the membrane. The possible reversion of water back diffusion through the membrane is also analyzed. The significant liquid permeation alleviates the possible anode flooding problem and cathode water scarcity, leading to faster reaction kinetics. These can also be confirmed by the EIS results. In addition, according to the in-situ EIS data, the membrane ohmic resistance is metastable under various operating pressures. In a word, this study gives a typical baseline of the operational capability of AEM fuel cell with various operating pressures, which offers an alternative approach to achieve a better water balance in an AEM fuel cell and enhanced fuel cell output capability. 


\section{Acknowledgements}

This work is supported by the National Natural Science Foundation of China for Excellent Young Scholars (Grant No. 51622606), and the Key Program of Natural Science Foundation of Tianjin (China) (Grant No. 16JCZDJC30800).

\section{References}

[1] M. Secanell, J. Wishart, P. Dobson, Computational design and optimization of fuel cells and fuel cell systems: A review. J. Power Sources 196 (2011) 3690-3704.

[2] X. Liu, F. Peng, G. Lou, Z. Wen, Liquid water transport characteristics of porous diffusion media in polymer electrolyte membrane fuel cells: A review. J. Power Sources 299 (2015) 85-96.

[3] S.M.R. Niya, M. Hoorfar, Study of proton exchange membrane fuel cells using electrochemical impedance spectroscopy technique - A review. J. Power Sources 240 (2013) 281-293.

[4] D.R. Dekel, Review of cell performance in anion exchange membrane fuel cells, Journal of Power Sources (2017) http://dx.doi.org/10.1016/j.jpowsour.2017.07.117.

[5] G.Merle, M. Wessling, K. Nijmeijer, Anion exchange membranes for alkaline fuel cells: A review. J. Membrane Sci. 377 (2011) 1-35.

[6] T. Zhou, R. Shao, S. Chen, X. He, J. Qiao, J. Zhang, A review of radiation-grafted polymer electrolyte membranes for alkaline polymer electrolyte membrane fuel cells. J. Power Sources 293 (2015) 946-975.

[7] A. Kucernak, F. Bidault, G. Smith, Membrane electrode assemblies based on porous silver electrodes for alkaline anion exchange membrane fuel cells. Electrochim. Acta 82 (2012) 284-290. [8] M. Mamlouk, K. Scott, J.A. Horsfall, C. Williams, The effect of electrode parameters on the performance of anion exchange polymer membrane fuel cells. Int. J. Hydrogen Energy 36 (2011) 7101-7198.

[9] D. Yang, H. Yu, G. Li, W. Song, Y. Liu, Z. Shao, Effect of gas diffusion electrode parameters on anion exchange membrane fuel cell performance. Chinese J. Catal. 35 (2014) 1091-1097.

[10] Z.F. Pan, R. Chen, L. An, Y.S. Li, Alkaline anion exchange membrane fuel cells for cogeneration of electricity and valuable chemicals. J. Power Sources 365 (2017) 430-445.

[11] A. Serov, et al., Hot topics in alkaline exchange membrane fuel cells, J. Power Sources (2017), 
https://doi.org/10.1016/j.jpowsour.2017.09.068.

[12] K. Vignarooban, J. Lin, A. Arvay, S. Kolli, I. Kruusenberg, K. Tammeveski, L. Munukutla, A. M. Kannan, Nano-electrocatalyst materials for low temperature fuel cells: A review. Chinese J. Catal. 36 (2015) 458-472.

[13] M.V. Martínez-Huerta, M.J. Lázaro, Electrocatalysts for low temperature fuel cells. Catal. Today 285 (2017) 3-12.

[14] N. Seselj, C. Engelbrekt, J. Zhang, Graphene-supported platinum catalysts for fuel cells. Sci. Bull. 60(9) (2015) 864-876.

[15] T.J. Omasta, L. Wang, X. Peng, C.A. Lewis, J.R. Varcoe, W.E. Mustain, Importance of balancing membrane and electrode water in anion exchange membrane fuel cells. J. Power Sources (2017), http://dx.doi.org/10.1016/j.jpowsour.2017.05.006.

[16] Y. Oshiba, J. Hiura, Y. Suzuki, T. Yamaguchi, Improvement in the solid-state alkaline fuel cell performance through efficient water management strategies. J. Power Sources 345 (2017) 221-226.

[17] D.R. Dekel, S. Willdorf, U. Ash, M. Amar, S. Pusara, S. Dhara, S. Srebnik, C.E. Diesendruck, The critical relation between chemical stability of cations and water in anion exchange membrane fuel cells environment. J. Power Sources (2017), http://dx.doi.org/10.1016/j.jpowsour.2017.08.026. [18] T. Reshetenko, M. Odgaard, D. Schlueter, A. Serovc, Analysis of alkaline exchange membrane fuel cells performance at different operating conditions using DC and AC methods. J. Power Sources (2017), http://dx.doi.org/10.1016/j.jpowsour.2017.11.030.

[19] S. Gottesfeld, D.R. Dekel, M. Page, C. Bae, Y. Yan, P. Zelenay, Y.S. Kim, Anion exchange membrane fuel cells: Current status and remaining challenges. J. Power Sources (2017), http://dx.doi.org/10.1016/j.jpowsour.2017.08.010.

[20] I.P. Raya, M.W. Ellis, A. Hernandez-Guerrero, F. Elizalde-Blancas, Modeling the effect of membrane conductivity on the performance of alkaline fuel cells. J. Power Sources 307 (2016) 898-906.

[21] D.R. Dekel, I.G. Rasin, M. Page, S. Brandon, Steady state and transient simulation of anion exchange membrane fuel cells. J. Power Sources (2017), http://dx.doi.org/10.1016/j.jpowsour.2017.07.012. 
[22] E.M. Sommer, L.S. Martins, J.V.C. Vargas, J.E.F.C. Gardolinski, J.C. Ordonez, C.E.B. Marino, Alkaline membrane fuel cell (AMFC) modeling and experimental validation. J. Power Sources 213 (2012) 16-30.

[23] S. Huo, H. Deng, Y. Chang, K. Jiao, Water management in alkaline anion exchange membrane fuel cell anode. Int. J. Hydrogen Energy 37 (2012) 18389-18402.

[24] H. Deng, S. Huo, Y. Chang, Y. Zhou, K. Jiao, Transient analysis of alkaline anion exchange membrane fuel cell anode. Int. J. Hydrogen Energy 38 (2013) 6509-6525.

[25] K. Jiao, P. He, Q. Du, Y. Yin, Three-dimensional multiphase modeling of alkaline anion exchange membrane fuel cell. Int. J. Hydrogen Energy 39 (2014) 5981-5995.

[26] K Jiao, S Huo, M Zu, D Jiao, J Chen, Q Du, An analytical model for hydrogen alkaline anion exchange membrane fuel cell. Int. J. Hydrogen Energy 40 (2015) 3300-3312.

[27] S. Huo, J.W. Park, P. He, D. Wang, K. Jiao, Analytical modeling of liquid saturation jump effect for hydrogen alkaline anion exchange membrane fuel cell. Int. J. Heat Mass Tran. 112 (2017) 891902.

[28] H. Deng, D. Wang, R. Wang, X. Xie, Y. Yin, Q. Du, K. Jiao, Effect of electrode design and operating condition on performance of hydrogen alkaline membrane fuel cell. Appl. Energ. 183 (2016) 1272-1278.

[29] H. Deng, D. Wang, X. Xie, Y. Zhou, Y. Yin, Q. Du, K. Jiao, Modeling of hydrogen alkaline membrane fuel cell with interfacial effect and water management optimization. Renew. Energ. 91 (2016) 166-177.

[30] Q. Ye, T.V. Nguyen, Three dimensional simulation of liquid water distribution in a PEMFC with experimentally measured capillary functions. J. Electrochem. Soc. 154 (12) (2007) B1242-B1251. [31] D.A.G. Bruggeman, The calculation of various physical constants of heterogeneous substances. I. The dielectric constants and conductivities of mixtures composed of isotopic substances. Ann. Phys. 24 (1935) 636-664.

[32] F.A.L. Dullien, Porous media: fluid transport and pore structure, 2nd ed., San Diego: Academic Press, 1992.

[33] K.S. Udell, Heat transfer in porous media considering phase change and capillarity-the heat pipe effect. Int. J. Heat Mass Transfer 28 (1985) 485-495. 
[34] Y.S. Li, T.S. Zhao, W.W. Yang, Measurements of water uptake and transport properties in anion-exchange membranes. Int. J. Hydrogen Energy 35 (2010) 5656-5665.

[35] Q. Duan, S. Ge, C.-Y. Wang, Water uptake, ionic conductivity and swelling properties of anion-exchange membrane. J. Power Sources 243 (2013) 773-778.

[36] S. Abdullah, S.K. Kamarudin, U.A. Hasran, M.S. Masdar, W.R.W. Daud, Electrochemical kinetic and mass transfer model for direct ethanol alkaline fuel cell (DEAFC). J. Power Sources 320 (2016) 111-119.

[37] P. S. Khadke, U. Krewer, Performance losses at $\mathrm{H}_{2} / \mathrm{O}_{2}$ alkaline membrane fuel cell. Electrochem. Commun. 51 (2015) 117-120. 